\title{
PHOTOKOPOLIMERISASI MONOMER AKRILAT DEGAN KULIT KRAS SAPI
}

Oleh : Dwi Wahini Nurhajati *), Agustin Suraswati *), Kadarijah **), dan Made Sumarti **).

\section{ABSTRACT}

The research on photocopolymerization of acrylate monomer with cow crust hide had object to observe the resulted copolymer onto cow crist hide. Crust hides, saturated with aqueous mulsions containing $25 w \%$ of n-hutvl acrvlate $(n-B A)$ or tripropvlene glvcol diacnvlate (TPGDA) were irradiated hy cohalt - 60 gamma rass wh doses ranges from $510 \quad 35 \mathrm{kG}$ The irradated hades were washed with water: dried in atr and extracted in sorthlet apparatus for 48 hours to remove homopolvmer. The highest vield of photocopolmerization of $n$. hath acrilate monomer with crust hides was found $17.7878^{\circ} \mathrm{n}$ at dose $25 \mathrm{kGv}$. and for photocopolymerization of tripropylene glycol diacrylate with crust hides was found $39.4245^{\circ}$, at dose $20 \mathrm{kGy}$

\section{INTISARI}

Penelitian photokopolymerisasi monomer akrilat dengan kulit kras sapi bertujuan untuk mengetahui banyaknya kopolimer yang dihasilkan didalam kulit kras sapi. Kulit kras yang sudah dijenuhkan dengan emulsi $n$ - butil akrilat atau tripropilena glikol diakrilat dalam air dengan konsentrasi monomer $25 \%$ berat, diiradiasi dengan sinar gamma kobalt - 60 dengan dosis yang bervariasi dari 5 sampai $25 \mathrm{kGy}$. Kulit yang sudah diiradiasi dicuci dengan air dikeringkan di udara dan diekstraksi dalam peralatan soxhlet selama 48 jam untuk menghilangkan homopolimer. Hasil tertinggi dari photokopolimerisasi monomer $n$ - butil akrilat dengan kulit dicapai pada dosis $25 \mathrm{kG}$ y yaitu sebesar $17.7878 \%$, dan untuk photokopolimerisasi monomer tripropilena glikol diakrilat dengan kulit dicapai pada dosis 20 kGy sebesar $39,4245 \%$

\section{PENDAHULUAN}

Photokopolimerisasi adalah proses pembentukan kopolimer menggunakan energi radiasi. Energi radiasi yang biasa digunakan pada proses photokopolimerisasi yaitu sinar gamma kobalt - 60, berkas elektron maupun sinar laser.

Proses photokopolimerisasi akhir-akhir ini banyak digunakan di berbagai industri di negara maju karena proses ini dikenal dapat memperbaiki mutu produkproduk polimer dalam waktu yang singkat dan tidak menimbulkan polusi udara.

Kulit kras merupakan polimer alam yang sebagian besar tersusun atas kolagen yang merupakan protein berserat ("fibrous protein").

*) Balai Besar Lit-Bang Kulit, Karet dan Plastik, Yogyakarta.

**) Pusat Aplikasi Isotop dan Radiasi (PAIR) - BATAN, Jakarta. 
Struktur kulit alam di seluruh bagian kulit tidak seragam, misal bagian perut strukturnya lebih longgar dari bagian kroupon. Keadaan ini menyebabkan bagian kulit yang longgar tidak dapat dipakai.Struktur kulit yang longgar dapat diperbaik dengan cara dicangkok ("grafting") dengan monomer, (1, 2, 3), menaikkan nilai teknis tersebut. Banyaknya kopolimer yang teradi di longgar ('gembos").

memperlihatkan bahwa struktur kulit tersebut lebih longgar "gembes").

Monomer akrilat yang banyak digunakan pada proses photopolimenisasi akrilat ( $\mathrm{n}$ - BA ), heksana diol diakrilat (HDDA), dictilena glikol diakrilat (DEGDA), tripropilena glikol diakrilat (TPGDA), trimetilol propana triakrilat ( TMPTA ), dan lain-lain.

Untuk mengetahui berapa banyak kopolimer yang dapat dibentuk di dalam kulit kras sapi maka dilakukan penelitian photokopolimerisasi monomer akrilat kiapi. Penelitian ini dilakukan bekerja sama dengan Pusat Aplikas dengan kulit kras sakarta, menggunakan 2 jenis monomer yaitu - butil akrilat ( $n-B A$ ) dan tripropilena glikol diakrilat (TPGDA).

\section{MATERI DAN METODE PENELITIAN}

1. Bahan

Bahan-bahan yang digunakan dalam penelitian ini adalah monomer $n$ butil akrilat ( n - BA ), monomer tripropilena glikol diakrilat ( TPGDA ), kulit kras sapi metanol, aseton, air destilasi, pengemulsi dino, dan kantong poli etilen.

2. Peralatan

Peralatan yang digunakan adalah :

Iradiator serbaguna milik PAIR -

soxhlet, labu destilasi, bekker glass.

3. Cara Penelitian

Penelitian dikerjakan dengan metode seperti pada Pustaka 1, 2 dan 3 yaitu:

3.1. Pengeringan kulit

Pulit, maka air yang ada di Agar supaya molik tidak dikungi. Kondisi dalam kulit harus dihiakan adalah 60 C, 24 jam.

pengeringan kulit yang dikerjakan ada

3.2. Pembuatan larutan emulsi - akrilat. Pengemulsi dino sebanyak $3 \%$ berat monomer dimasukkan ke dak destilasi dan diaduk sampai homogen kensentrasi moriomer $25 \%$ ditambahkan kedalam larutan pengemulsi deng berat, diaduk sampai homogen.

3.3. Impregnasi dan iradiasi. Kulit kras kering diimpregnasi dengan larutanietilen, diseal, lalu diiradiasi kemudian dimasukkan kedalam kantong polietilen, diseal, lalu diiradiasi dengan sinar gamma kobalt - 60 didalam sebuah iradiator dengan dosis yang bervariasi yaitu $5-25 \mathrm{kGy}$.

3.4. Prosedur Analisa

Kulit yang sudah diiradiasi dicuci dengan air sampai bersih untuk menghilangkan bahan pengemulsi dan kelebihan monomer akrilat. Selanjutnya kulit dikeringkan dalam udara dan diekstraksi didalam peralatan soxhlet selama 48 jam untuk menghilangkan homopolimer. Pelarut yang digunakan untuk mengekstraksi kulit yang dikopolimerisasi dengan monomer n - butil akrilat ( $\mathrm{n}$ - BA ) adalah etil asetat, sedangkan untuk mengekstraksi kulit yang dikopolimerisasi dengan monomer tripropilena glikol diakrilat ( TPGDA ) menggunakan pelarut acetone. Jumlah homopolimer ditentukan dengan presipitasi larutan dalam metanol.

Kandungan polimer total yang terjadi di dalam kulit dihitung berdasarkan perbedaan berat dengan rumus :

$$
\begin{aligned}
& \text { PT = } \\
& \begin{array}{l}
\mathrm{W}_{1}-\mathrm{W}_{0} \\
\mathrm{~W}
\end{array} \text { = kandungan polimer total yang terjadi. } \\
& \mathrm{W} 0=\text { berat kulit kering sebelum diimpregnasi. } \\
& \mathrm{W} 1=\text { berat kulit kering setelah diimpregnasi. }
\end{aligned}
$$

Kopolimer yang terjadi dihitung berdasarkan selisih berat kandungan polimer total dengan homopolimer.

\section{IIASIL PENELITIAN DAN PEMBAHASAN}

Hasil kopolimerisasi monomer n - butil akrilat ( n - BA ) dengan kulit dapat dilihat pada tabel 1, sedangkan hasil kopolimerisasi monomer tripropilena glikol diakrilat ( TPGDA ) dengan kulit dapat dilihat pada tabel 2.

Tabel 1. Prosentase Polimer dalam kulit yang dikopolimerisasi dengan $\mathrm{n}$ - butil akrilat ( $\mathrm{n}-\mathrm{BA}$ ).

\begin{tabular}{|c|c|c|c|}
\hline $\begin{array}{c}\text { Dosis iradiasi } \\
\text { kGy }\end{array}$ & $\begin{array}{c}\text { Polimer total } \\
\%\end{array}$ & $\begin{array}{c}\text { Homopolimer } \\
\%\end{array}$ & $\begin{array}{c}\text { Kopolimer } \\
\%\end{array}$ \\
\hline 5 & 6,4660 & 0,4488 & 6,0372 \\
10 & 15,3281 & 0,1020 & 15,2261 \\
15 & 11,5001 & 0,0700 & 11,4301 \\
20 & 14,5785 & 0,1257 & 14,4528 \\
25 & 18,8484 & 1,0606 & 17,7878 \\
\hline
\end{tabular}


Tabel 2. Prosentase Polimer dalam kulit yang dikopolimerisasi dengan tripropilena glikol diakrilat ( TPGDA ).

\begin{tabular}{|c|c|c|c|}
\hline $\begin{array}{c}\text { Dosis iradiasi } \\
\text { kGy }\end{array}$ & $\begin{array}{c}\text { Polimer total } \\
\%\end{array}$ & $\begin{array}{c}\text { Homopolimer } \\
\%\end{array}$ & $\begin{array}{c}\text { Kopolimer } \\
\%\end{array}$ \\
\hline 5 & 32,1382 & 0,8215 & 31,3167 \\
10 & 32,6913 & 0,0979 & 32,5934 \\
15 & 38,900 & 0,0800 & 38,8200 \\
20 & 39,7683 & 0,3438 & 39,4245 \\
25 & 26,0731 & 0,0015 & 26,0716 \\
\hline
\end{tabular}

Pada tabel 1 dan 2 terlihat bahwa pada umumnya dengan naiknya dosis iradiasi maka polimer yang terjadi juga mengalami kenaikan, kecuali untuk kulit yang dikopolimerisasi dengan tripropilena glikol diakrilat pada dosis $25 \mathrm{kGy}$ polimer yang terjadi mengalami penurunan.

Banyaknya-polimer yng terjadi ini juga tergantung banyaknya monomer yang terserap oleh kulit. Dari hasil pengamatan ternyata bahwa banyaknya monomer yang terserap tergantung struktur dari kulit itu sendiri. Untuk kulit yang strukturnya lebih longgar ternyata lebih banyak menyerap monomer sehingga polimer yang terbentuk lebih banyak menyerap monomer sehingga polimer yang terbentuk juga lebih banyak dibandingkan dengan kulit yang strukturnya lebih rapat.

Rendahnya prosentase polimer yang terbentuk ini kemungkinan juga dikarenakan waktu perendaman monomer yang kurang lama. Menurut $\mathrm{K}$. Pietrucha, dkk ( 1981 ), waktu perendaman monomer adalah 2 jam di dalam drum yang berputar. Mengingat keterbatasan alat, maka pada penelitian ini hanya direndam selama 2 jam pada suatu tempat dengan diaduk-aduk. Oleh karena itu mungkin memerlukan waktu perendaman yang lebih lama.

Dari analisa homopolimer yang terjadi, ternyata bahwa homopolimer terendah untuk kulit yang dikopolimerisasi dengan $\mathrm{n}$ - butil akrilat dicapai pada dosis $15 \mathrm{kGy}$, sedangkan untuk kulit yang dikopolimerisasi dengan trpropilena glikol diakrilat dicapai pada dosis $25 \mathrm{kGy}$.

\section{KESIMPULAN}

1. Hasil photokopolimerisasi kulit dengan monomer n - butil akrilat ( $\mathrm{n}$ - BA ) tertinggi diperoleh pada dosis $25 \mathrm{kGy}$ yaitu sebanyak $17,7878 \%$.

2. Hasil photopolimerisasi kulit dengan monomer tripropilena glikol diakrilat ( TPGDA ) tertinggi dicapai pada dosis $20 \mathrm{kGy}$ yaitu sebesar $39,4245 \%$.

\section{DAFTAR PUSTAKA}

1. Dwi Wahini Nurhajati, Penny Setyowati, Kadarijah, Agustin Surawasti, Pramono dan Made Sumarti, "Sifat Kulit Kras Sapi Hasil Modifikasi dengan TPGDA secara Radiasi, Proceedings Simposium Nasional Perkulitan, halaman 126 - 130, 1993.

2. Dwi Wahini Nurhajati, Sulistyah Wrd., Kadarijah, Penny Setyowati, "Penelitian Penggunaan Monorer-Buletin Akrilat untuk Peningkatan Mutu Kulit secara iradiasi", Majalah Barang Kulit, Karet dan Plastik, Vol. XI No. 21, Halaman 1-6, tahun 1995/1996.

3. K. Pietrucha, W. Pekala, and I. Kroh, "Radiasi Induced Graft Copolymerization of Metyl Methacrylate onto Chrome Tanned Pig Skins", Radiat. Phys. Chem. Vol. 18 No. 3-4. pp. 489-501. 1981. 